\title{
Correction to: Punching above their weight, but why? Explaining Denmark and Estonia in the transatlantic relationship
}

\section{Anders Wivel ${ }^{1} \cdot$ Matthew Crandall $^{2}$}

Published online: 28 November 2019

(c) The Author(s) 2019

\section{Correction to: Journal of Transatlantic Studies (2019) 17:392-419 https://doi.org/10.1057/s42738-019-00020-2}

Open Access This article is distributed under the terms of the Creative Commons Attribution-NonCommercial 4.0 International License (http://creativecommons.org/licenses/by-nc/4.0/), which permits any noncommercial use, duplication, adaptation, distribution and reproduction in any medium or format, as long as you give appropriate credit to the original author(s) and the source, a link is provided to the Creative Commons license and any changes made are indicated.

The original article can be found online at https://doi.org/10.1057/s42738-019-00020-2.

Anders Wivel aw@ifs.ku.dk

1 Copenhagen, Denmark

2 Tallinn, Estonia 